\title{
Pluralisme Masyarakat Adat Donggo Dalam Merawat Kerukunan Beragama
}

\author{
Lutfin Haryanto ${ }^{1}$, Abas Oya ${ }^{2}$, Jessy Parmawati Atmaja ${ }^{3}$ \\ Dosen Sekolah Tinggi Keguruan dan Ilmu Pendidikan Harapan Bima 1, 2,3 \\ Email: lutfinharyanto1990@gmail.com ${ }^{1}$, parmawatijessy@gmail.com ${ }^{2}$, abasoya01@gmail.com ${ }^{3}$
}

\begin{abstract}
Pluralism is a view of life in understanding, acknowledging and accepting the existence of pluralism and diversity in a community group. The people of Donggo, Bima Regency, West Nusa Tenggara have different religious beliefs, in which there are different cultures and customs. There are three religions that developed in Palama Village 2, Nggerukopa hamlet, Donggo District, namely Islam, Catholicism and Protestantism. With a variety of religious beliefs, of course, each individual community has different desires, and this can lead to conflict between individuals in the community, for this reason it is necessary to understand pluralism which refers to the meaning of tolerance in order to live in harmony, to unite the diversity of a nation. The formulation of the problem raised in this study is how is the form of religious harmony in the Donggo custom community? The formulation of the problem raised. The purpose of this study is to find out the pluralism of the Donggo custom people in maintaining religious harmony. Researchers obtain data in this study is from observation, interviews and documentation. The data were analyzed by qualitative descriptive method. Based on the results of the study it was found that the forms of harmony of the Donggo custom people in maintaining religious harmony were cua kaco' $i$ angi (mutual respect), doho kaboro weki (sitting together), inga dasa uma (helping to build a house), batu rawi rasa (participating in events) and tio kasama weki rasa ra dana (guarding with the village). Thus, the researcher concludes that the Donggo custom people in Nggerukopa really care for their religious harmony in any form to continue to live in harmony with each other.
\end{abstract}

Keywords: Pluralism, Donggo custom, Religious Harmony

\begin{abstract}
Abstrak
Pluralisme adalah pandangan hidup dalam memahami, mengakui dan menerima adanya kemajemukan dan keanekaragaman dalam suatu kelompok masyarakat. Masyarakat Donggo, Kabupaten Bima, Nusa Tenggara Barat terdapat kepercayaan beragama yang berbeda, yang didalamnya terdapat budaya dan adat istiadat yang berbeda pula. Ada tiga agama yang berkembang di Desa Palama 2 dusun Nggerukopa Kecamatan Donggo yaitu Islam, Katolik dan Protestan. Dengan beraneka ragamnya kepercayaan beragama, tentu setiap masing-masing individu masyarakat mempunyai keinginan yang berbeda-beda, dan hal tersebut bisa menimbulkan konflik diantara individu masyarakat tersebut, untuk itulah diperlukan paham pluralisme yang mengacu kepada arti toleransi supaya hidup rukun, untuk mempersatukan kebhinekaan suatu bangsa. Rumusan masalah yang diangkat pada penelitian ini adalah bagaimana bentuk kerukunan beragama di masyarakat adat Donggo?, Tujuan penelitian ini ialah mengetahui pluralisme masyarakat adat Donggo dalam merawat kerukunan beragama. Peneliti memperoleh data dalam penelitian ini ialah dari observasi, interview dan dokumentasi. Data tersebut dianalisis dengan metode deskriptif kualitatif. Berdasarkan hasil penelitian yang ditemukan bahwa bentuk kerukunan masyarakat adat Donggo dalam merawat kerukunan beragama ialah cua kaco'i angi (saling menghargai), doho kaboro weki (duduk bersama), inga dasa uma (bantu membangun rumah), batu rawi rasa (ikutserta dalam acara) serta tio kasama weki rasa ra dana (menjaga bersama desa dan kampung). Dengan demikian, peneliti menyimpulkan masyarakat adat donggo di Nggerukopa sangat merawat kerukunan beragama mereka dengan bentuk apapun untuk tetap menjalani hidup rukun satu sama lain.
\end{abstract}

Kata kunci: Pluralisme, Adat Donggo, Kerukunan Beragama

\section{PENDAHULUAN}

Pluralisme adalah pandangan hidup dalam memahami, mengakui dan menerima adanya kemajemukan dan keanekaragaman dalam kelompok masyarakat. Kemajemukan adalah sebuah fenomena yang mustahil dihindari terutama kemajemukan agama. Masyarakat Indonesia termaksud masyarakat majemuk, yang terdiri dari berbagai kelompok umat beragama, suku, dan ras, dan memiliki budaya dan adat istiadat yang berbeda. Salah satunya ialah masyarakat Donggo, Kabupaten Bima, Nusa Tenggara Barat yang memiliki kepercayaan beragama yang berbeda, yang didalamnya terdapat budaya dan adat istiadat yang berbeda pula. Ada tiga agama yang berkembang di Desa Palama (Nggerukopa) Kecamatan Donggopada saat ini, yaitu Islam, Katolik dan Protestan.

Dengan beraneka ragamnya kepercayaan beragama, tentu setiap masing-masing individu masyarakat mempunyai keinginan yang 
berbeda-beda, dan hal tersebut dapat menimbulkan konflik di antara masyarakat, untuk itulah diperlukan paham pluralisme yang mengacu kepada arti toleransi supaya hidup rukun. Hal itu untuk mempersatukan kebhinekaan bangsa. Hidup rukun karena perbedaan ras, suku, budaya bahkan adat istiadat telah menjadi hal yang lazim, dan tidak terlalu menimbulkan masalah yang signifikan.

Akan tetapi, kerukunan beragama membutuhkan alasan dan keyakinan yang kuat dari kepercayaaan masing-masing, dikarenakan banyak pertimbangan untuk selalu menjaga kerukunan. Jika pertanyaan tersebut terus selalu dipertanyakan, masalah dan konflik dapat muncul walaupun perilaku dan ucapan yang dilakukan memiliki sikap yang sepele.

Konflik antarpemeluk yang berbeda agama dan antaretnik di Indonesia selalu muncul baik secara terlihat maupun laten. Konflik tersebut dicirikan sebagai persaingan untuk mencari pendukung dan persaingan untuk kemurnian dan keaslian dari ajaran agama masing-masing. Walaupun demikian Negara Kesatuan Republik Indonesia (NKRI) telah berkomitmen bahwa modal dasar multikultural dan multiagama itu harus dirangkai dengan sikap toleransi dan jiwa integrasi.

Kerukunan beragama merupakan salah satu arti dari sebuah toleransi. Prilaku ini sudah menjadi hal yang lumrah di Desa Palama 2 (Nggerukopa). Masyarakat multiagama Nggerukopa saling menghargai dan mendorong satu sama lain dalam melakukan ibadah masingmasing. Oleh karena itu, menaruh minat peneliti untuk mengetahui pluralisme masyarakat adat Donggo dalam merawat kerukunan beragama.

Penelitian mengenai pluralisme telah diteliti oleh pelbagai peneliti. Peneliti-pebeliti tersebut dapat diuraikan sebagai berikut. Sumitro (2020) dalam tulisannya berjudul Pelestarian Nilai Budaya Kaco'i Angi Pada Masyarakat Donggo. Penelitian ini bertujuan untuk mengetahui lebih komprehensif tentang makna yang terkandung dalam nilai budaya kaco'I angi pada masyarakat Donggo. Hasil penelitian ini mengungkapkan bahwa kaco'i angi tidak dimaknai sebagai sekadar slogan menghormati antarsesama. Kata kaco'i angi lebih menekankan pada proses penanaman nilai moralitas pada generasi penerus serta menjadi pegangan hidup bagi generasi Donggo dalam hidup di masyarakat. Penanaman itu dilakukan pada lingkungan masyarakat Donggo dan masyarakat Bima pada umumnya.

Julita Lestari (2020) dalam judul tulisannya Pluralisme Agama di Indonesia: Tantangan dan Peluang Bagi Keutuhan Bangsa. Adapun hasil penelitiannya memaparkan bahwa keberagaman agama di satu sisi cenderung melahirkan perpecahan di kalangan umat beragama. Di sisi lain persatuan yang didorong oleh sikap saling menghargai akan perbedaan yang ada. Penelitian tersebut mengkaji kedua sisi pluralisme di Indonesia sebagai negara yang terbangun dari keragaman agama. Pluralitas agama di Indonesia memiliki tantangan dan peluang bagi keutuhan bangsa. Tantangan terbesar pluralitas bangsa ini adalah kecenderungan konflik yang bersumber dari truth claim (klaim kebenaran) masing-masing kelompok keagamaan. Sementara peluang pluralitas adalah sikap toleransi masing-masing penganut agama yang menopang keutuhan bangsa.

I Made Purna (2016) dalam tulisannya berjudul Kearifan Lokal Masyarakat Desa Mbawa dalam Mewujudkan Toleransi Beragama. Tujuan penelitian tersebut dimaksudkan untuk mengkaji masyarakat Desa Mbawa yang terdiri atas berbagai macam penganut agama dapat menghindari konflik berbasis agama. Strategi yang digunakan sebagai wahana mewujudkan keharmonisan masyarakat Desa Mbawa. Metode observasi digunakan sebagai tumpuan utama dalam penelitian ini. Adapun penelitian ini ialah kearifan lokal yang hidup di Desa Mbawa mampu menjembatani anggota masyarakat yang berbeda keyakinan.

Casram (2016) dalam judul tulisannya Membangun Sikap Toleransi Beragama dalam Masyarakat Plural. Tujuan penelitiannya agar kehidupan beragama dapat terbina harmonis. Adapun hasil penelitiannya memaparkan bahwa penghayatan dan praktik keagamaan tidak berhenti pada tahap klaim eksklusifisme ("Aku") yang berujung pada hubungan personal dengan Tuhan (soliter), tidak juga pada tahap inklusifisme ("Kamu”) dengan perhatiannya 
pada perekrutan dukungan teologis atau ideologis (solidaritas), melainkan juga tahap keterbukaan ("Kita"), dan penghayatan religius atas nilai-nilai kemanusiaan mendapat penekanan (humanis).

Novita Dewi Masyithoh (2016) dalam judul tulisanya Dialektika Pluralisme Hukum: Upaya Penyelesaian Masalah Ancaman Keberagaman dan Keberagamaan di Indonesia. Penelitian tersebut adalah penelitian hukum dengan tradisi kualitatif yang berusaha mendialektikan tiga dimensi dari legal pluralisme, yaitu natural law, state law dan law society. Penelitian tersebut menggunakan data sekunder, dengan bahan hukum primer dan sekunder yang diperoleh dengan teknik dokumentasi. Data dianalisis secara induktif dengan menggunakan teori-teori yang ada untuk memproduksi suatu proposisi yang umum, sehingga menghasilkan kesimpulan dan rekomendasi. Hasil penelitian menunjukkan bahwa telah terjadi delapan konflik SARA di Indonesia dalam tiga tahun terakhir. Untuk memecahkan masalah tersebut, para pemuka agama menggunakan pendekatan natural law untuk reinternaliasasi nilai-nilai keluhuran atas agama dan toleransi. Perlu kebijakan nonpenal dengan seruan-seruan persuasif agar persoalan serupa tidak lagi terjadi. Di sisi lain, kebijakan penal melalui penegakan hukum harus dilakukan, sebagai bentuk state positivism law. State positivism law harus mampu menggandeng natural law dan law society, agar diperoleh putusan terbaik yang berlandaskan nilai-nilai moral ethic religion dan nilai-nilai sosial kemasyarakatan.

Umi Sumbulah (2015) dalam judul tulisanya Pluralisme dan Kerukunan Umat Beragama Perspektif Elite Agama di Kota Malang. Data penelitian empiris dengan pendekatan kualitatif-fenomenologis tersebut dikumpulkan melalui wawancara dan dokumentasi. Hasil penelitian menunjukkan: pertama, makna pluralisme agama bagi elit agama-agama sangat variatif, yakni sama dengan toleransi, saling menghargai, tujuan semua agama sama, dan menyadari kenyataan bahwa terdapat banyak agama di dunia ini. Kedua, kerukunan umat beragama memiliki makna sebagai kondisi tidak ada opresi dan dominasi satu agama atas agama lain, terbangunnya kesadaran mendalam atas keragaman, penghormatan atas hak asasi manusia, dan kemauan untuk menebar kebaikan dan cinta kasih kepada sesama manusia. Ketiga, kerukunan umat beragama dapat diwujudkan melalui upaya-upaya internal dengan penguatan keimanan masing-masing dan membangun kesadaran untuk mengembangkan sikap positif terhadap agama lain. Secara ekternal upaya menciptakan kerukunan dilakukan melalui dialog emansipatoris dan kerjasama untuk menyeleseaikan masalah kemanusiaan. Keempat, sikap positif yang mendukung terciptanya harmoni agama-agama adalah adanya kemauan dan kesadaran untuk saling memahami dan berbagi pengalaman. Egoisme, truth claim, fanatisme, dan eksklusivisme merupakan sikap dan ekspresi negatif yang disadari oleh para elite agama dapat mengganggu terbangunnya keharmonisan antarumat beragama.

\section{METODE}

Penelitian ini merupakan penelitian kualitatif. Jenis penelitian yang menggunakan teori-teori dan informasi-informasi yang dijadikan sebagai bahan analisis dari permasalahan yang diteliti. Penelitian ini menggunakan pendekatan atau teknik purposive sampling. Metode yang digunakan yaitu deskriptif. Penelitian kualitatif deskriptif adalah berupa penelitian dengan metode atau pendekatan studi kasus.

Sumber data dalam penelitian ini yaitu informasi-informasi yang dikumpulkan dengan menggunakan teknik observasi, wawancara dan dokumentasi. Teknik tersebut dilakukan peneliti untuk pengumpulan data terhadap masyarakat Donggo yang menganut perbedaan agama dan pengalaman pribadi mereka yang terkait dengan bentuk kerukunan dan implementasinya. Peneliti memperoleh data atau informasi dalam penelitian ini dari hasil: 1) Observasi dilakukan dengan mengamati tempat penelitian secara langsung, 2) Wawancara terhadap tokoh-tokoh dan pemerintah. 3) Dokumentasi semua tahapan penelitian yang dilakukan.

Teknik analisis data yang digunakan yaitu teknik analisis deskriptif. Teknik analisis 
deskriptif dalam peneltian ini yaitu menginterpretasikan data dengan memberikan penjelasan mengenai data. Tahap menganalisis data yaitu menguraikan data berdasarkan teoriteori yang dipakai. Tahap penarikan simpulan akhir yaitu menyajikan data yang telah diinterpretasi dan dianalisis pada bagian hasil dan pembahasan.

Langkah-langkah penelitian diawali dengan perencanaan yaitu melakukan studi literatur, analisis kebutuhan (adat donggo), dan merumuskan permasalahan. Tahap pelaksanaan, yaitu menentukan sumber data, mengumpulkan data, menyajikan dan menganalisis data. Tahap penyelesaian yaitu menyusun naskah, seminar dan publikasi.

\section{HASIL DAN PEMBAHASAN}

Pluralisme pada masyarakat sangat tinggi dalam kehidupan masyarakat Donggo. Salah satu bentuk pluralisme yang direpresentasikan masyarakat Donggo adalah mengenai keyakinan dalam beragama. Uraian dalam pembahasan ini akan menjelaskan secara komprehensif pelbagai pluralisme yang ada di lingkungan masyarakat Donggo. Penjabaran tersebut dapat diuraikan sebagai berikut.

\section{Deskripsi Umum Dusun Nggerukopa, Desa Palama Kecamatan Donggo}

Dusun Nggerukopa berlokasi di Desa Palama, Kecamatan Donggo, Kabupaten Bima. Dusun Nggerukopa terletak di bagian barat dari wilayah Donggo, tepatnya berada di kaki gunung Salunga. Masyarakat luar mengenalnya dengan kata "Doro Donggo". Dusun Nggerukopa banyak dihuni oleh dusun yang ada di Desa Palama.

Dusun Nggerukopa memiliki posisi jauh dengan dusun-dusun yang ada di Kecamatan Donggo. Perjalanan menuju Dusun Nggerukopa ke Kantor Desa Palama membutuhkan waktu lima menit dengan mengendarai sepeda motor. Masyarakat Dusun Nggerukopa memiliki profesi sebagai petani, pekebun, peternak, dan ASN. Akan tetapi, masyarakat umum mengenal masyarakat Dusun Nggerukopa dengan profesi sebagai penenun.

Sebagai masyarakat pluralisme, Dusun Nggerukopa memiliki pelbagai keyakinan, Islam, Kristen Protestan, dan Krist Katolik.
Adanya pluralisme tersebut, masyarakat Dusun Nggerukopa memiliki tempat ibadah yang beragam. Sebagai masyarakat pluralisme, lokasi ibadah di Dusun Nggerukopa sangat berdampingan. Bahkan berhadapan dengan dibatasi oleh gang.

\section{Kehidupan Beragama di Nggerukopa}

Terdapat pelbagai kalangan masyarakat Desa Palama memberikan perhatian yang cukup besar mengenai fenomena-fenomena keagamaan dalam lingkungan sosial masyarakat Nggerukopa. Salah satu fenomena sosial yang diperhatikan oleh masyarakat Dusun Palama pernikahan berbeda agama. Hakikatnya, permasalahan nikah berbeda agama di lingkungan masyarakat Dusun Nggerukopa telah menjadi perihal yang lumrah. Hal itu merupakan wujud sikap pluralisme masyarakat Nggerukopa dalam menjalani hidup agar tidak menimbulkan konflik.

Hal tersebut sebagai salah satu wujud bahwa hidup rukun bagi umat yang menganut agama yang berbeda terjalin dengan baik. Agama yang diakui, diikuti, atau diyakini sebagai pedoman hidup dan sebagai kebenaran mutlak maka akan memiliki nilai dinamis, universal, fleksibel dan berorientasi ke depan baik bagi para penganutnya. Dengan begitu, dinamika kehidupan beragama dapat dilihat dari para penganutnya (Ghazali \& Busro, 2017).

Setiap pemeluk agama memiliki ketentuan ajarannya masing-masing dengan penuh kesadaran untuk tidak saling membenarkan agama yang dianutnya. Sebab masing-masing agama mempunyai ajaran-ajaran tertentu, yang membedakan dan memiliki ciri-ciri khas dari yang lain. Perbedaan-perbedaan yang ada di antara agama-agama dalam berinteraksi secara penuh, tidak menonjolkan identitas agama yang dianut, dan juga tidak mengaktifkan simbolsimbol agama termasuk telah menghargai perbedaan-perbedaan yang ada.

Dengan demikian wujud toleransi atau kerukunan antar umat beragama akan terlaksana ketika terwujud interaksi antarumat beragama tidak saling merugikan satu sama lain. Setiap agama harus melaksanakan dan menggariskan dua pola hubungan setiap pemeluknya untuk mewujudkan kebaikan, yaitu hubungan yang bersifat horizontal dan hubungan yang bersifat 
vertikal. Hubungan yang bersifat horizontal atau pola hubungan manusia dengan masyarakat sekitar atau hubungan manusia dengan sesamanya yang berbeda ras, kebudayaan, agama baik itu dalam bentuk kemasyarakatan seperti bekerja sama, ataupun pola individu dengan individu untuk menjalin rasa persaudaraan yang lebih erat. Sedangkan hubungan vertikal membentuk hubungan manusia dengan penciptanya diwujudkan dengan setiap harinya beribadah sebagaimana digariskan pada tiap-tiap agama (Pradipta, et al., 2021).

\section{Posisi Agama dalam Masyarakat Donggo di Nggerukopa}

Menurut MacIver, masyarakat dibentuk oleh struktur yang tidak kelihatan dan merupakan kumpulan dari beragam hubungan manusia yang dibangun dan diubah oleh manusia itu sendiri (James. D. Proctor, 2005:90). Masyarakat bergerak secara dinamis sesuai dengan perkembangan dan kemajuan zaman. Bagi masyarakat Donggo di Nggerukopa khususnya, agama dimaknai sebagai alat kontrol dalam aktivitasnya dalam kesehariannya. Sehinggga bukan hal baru lagi bahwa masyarakat Donggo mendorong anakanaknya untuk menuntut ilmu walaupun dengan kondisi ekonomi yang tidak memungkinkan, sebab menurut petuah-petuah lebih baik buta dengan urusan dunia daripada buta tentang ajaran keagamaan. Sehingga asumsi masyarakat Donggo untuk mendorong anak-anaknya untuk mengaji, shalat dan kegiatan-kegiatan keagamaan lainnya menjadi prioritas utama.

Masyarakat Donggo sangat kental dengan nilai-nilai budaya, misalnya budaya kaco' $i$ angi. Hal itu memberikan nilai khusus sebagai cerminan sesorang yang memahami konsep keagamaan yang lengkap dan sempurna. Walaupun pada masyarakat Donggo di Nggerukopa terdapat tiga agama yang berbeda, namun kehidupan beragamanya sangat harmonis bukan karena ada hubungan darah atau homogeni yang sama. Akan tetapi lebih pada melekatnya pemaknaan budaya kaco'i angi yang sudah mendarah daging di setiap anggota masyarakat Donggo tepanya di lingkungan masyarakat Nggerukopa. Berdasarkan itu yang menarik peneliti untuk menemukan pada masyarakat Donggo di dusun Nggerukopa. Agama bagi masyarakat sudah dititik akhir, tetapi dalam pengimplementasikan nilainilainya perlu kecarmatan dan kehati-hatian demi terwujudnya kehidupan yang aman dan damai bagi semua pemeluk agama yang ada didalamnya.

Karakter interaksi antarkebudayaan dalam masyarakat multikultural adalah terjadinya asimilasi kebudayaan. Tidak hanya itu, dalam multicultural terjadi pada keberagamaan. Orangorang yang hidup dalam masyarakat multikultural berasimilasi mengenai keberagamaan yang baik dalam masyarakat dengan komposisi kepemelukan agama yang heterogen. Beda halnya dengan masyarakat Donggo di Nggerukopa dalam hubungan sosialnya tetap menjunjung tinggi nilai-nilai persaudaraan. Hal itu menciptakan suasana perdamaian dan rasa toleransi serta kerjasama antar budaya-agama.

Tokoh Islam, bernama Husain Hasin dan tokoh adat H. M. Noer, di lingkungan masyarakat Dusun Nggerukopa, memaknai kerukunan umat beragama dalam aspek kerukunan bersifat internal dan antaragama. Kerukunan internal umat beragama di Dusun Nggerukopa, menitikberatkan pada sikap toleransi terhadap sesama Muslim. Sementara kerukunan antaragama ialah saling menghormati dan toleransi terhadap umat agama yang berbeda. Artinya ketika umat Kristiani merayakan Ibadah Natal, umat Islam memberikan izin dan membantu keamanan acara. Sikap demikian, akan dilakukan oleh umat Kristiani ketika umat Islam melaksanakan ibadah Salat Ied, akan membantu pelaksanaan ibadah meski pelaksanaan bersinggungan dengan ibadah umat Kristiani yang dilaksanakan pada hari Minggu.

Menurut Pendeta Andreas Passa memaknai kerukunan dapat dilaksanakan berdasarkan kasih. Artinya ketika terjadi aktivitas kejahatan tidak dibalas dengan kejahatan. Akan tetapi, dibalas dengan doa. Selanjutnya menurut Pendeta Andreas Passa, bahwa kerukunan berasal dari teologis kerukunan umat beragama dalam umat Kristiani ialah agama dapat memberikan berkat bagi semua manusia. Sementara berdasarkan 
landasan historis bersumber dari asal-usul agama Ibrahim. Adanya persamaan ajaran agama tersebut merupakan bentuk isyarat bahwa semua manusia dapat menjalin kehidupan yang rukun.

Pendeta Sam Latunussa, kerukunan di lingkungan masyarakat Nggerukopa dapat dimulai dengan aktivitas kecil masyarakat yang berhubungan dengan kehidupan sehari-hari. Hal itu tercerminkan pada aktivitas duduk bersama dalam mendiskusikan permasalahan desa. Pendeta Sam Latunussa, turut mengemukakan bahwa kerukunan antarumat beragama di Dusun Nggerukopa dapat dimaknai sebagai bentuk kebersamaan. Hal itu dikarenakan dalam ajaran Alkitab mengajarkan mengenai kasih sayang, "kasihlah sesamamu, seperti kalian mengasihi diri sendiri". Jika melihat hal itu, perintah dalam menyayangi tidak hanya diterapkan dalam umat kristiani, terhadap agama lain.

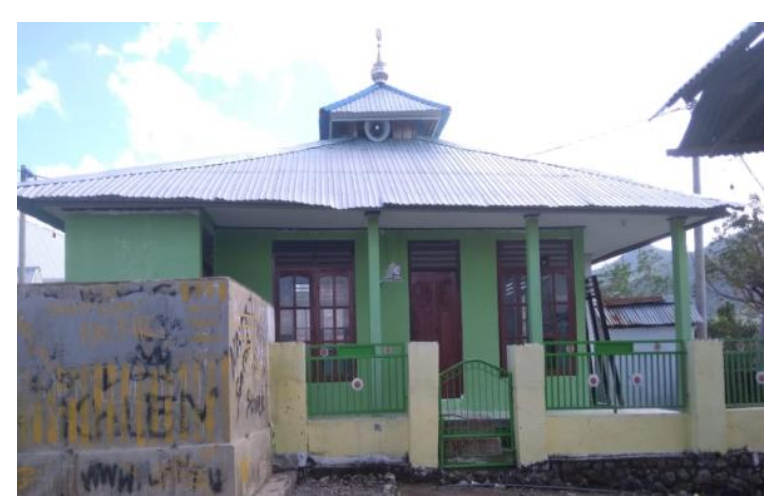

Gambar 1. Masjid Ar- Rahman Masyarakat Donggo

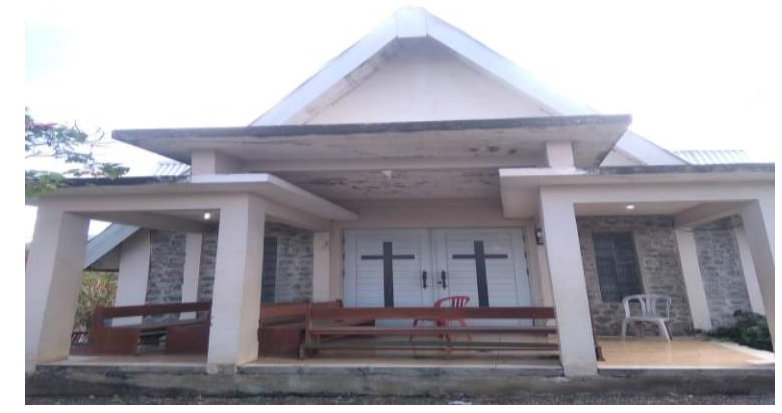

Gambar 2. Gereja Katolik Santo Petrus Masyarakat Donggo

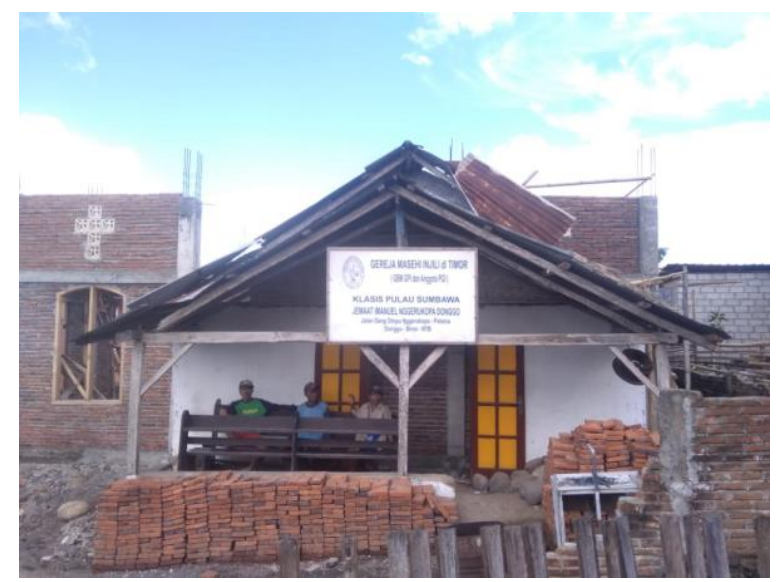

Gambar 3. Gereja Protestan Gemit Imanuel Masyarakat Donggo

\section{Bentuk-Bentuk Kerukunan Masyarakat Donggo Nggerukopa}

Aktivitas kehidupan masyarakat Donggo Nggerukopa merepresentasikan intensi pluralisme yang cukup tinggi. Perilaku itu tidak hanya di cerminkan dalam kegiatan keagamaan, akan tetapi, turut direpresentasikan dalam bentuk aktivitas sehari-hari. Adapun bentuk-bentuk kerukunan masyarakat Donggo dapat diuraikan berikut.

Cua kaco'i angi (saling menghargai)

Bentuk cua kaco' $i$ angi tersebut di antaranya menghargai umat agama lain dalam menjalankan ibadahnya tanpa mengganggu dan mempermasalahkan aktivitasnya. Bahkan ikut menjaga ketertiban sehingga umat agama lain dengan tenang melakukan ibadahnya. Perbedaan agama yang diyakinin masyarakat donggo dusun nggerukopa bukan lagi menjadi penghambat dan menutup diri dalam melakukan dan melaksanakan kehidupan sehari-hari tanpa berintraksi dengan kelompok lain hanya karena perbedaan agama yang dianut. Agama yang diakui, diikuti, atau diyakini sebagai pedoman hidup dan sebagai kebenaran mutlak maka akan memiliki nilai dinamis, universal, fleksibel dan berorientasi kedepan baik bagi para penganutnya. Dengan begitu dinamika kehidupan beragama dapat dilihat dari para penganutnya (Ghazali \& Busro, 2017).

Doho kaboro weki (duduk bersama)

Doho kaboro weki ini sering dilakukan oleh masyarakat Nggerukopa sebagai ajang silaturahmi tanpa mempermasalahkan dan menghiraukan dia atau mereka dari agama lain. Perbedaan agama yang diyakinin masyarakat donggo dusun nggerukopa bukan lagi menjadi penghambat dan menutup diri dalam melakukan dan melaksanakan kehidupan sehari-hari tanpa berintraksi dengan kelompok lain hanya karena perbedaan agama yang dianut. Agama yang diakui, diikuti, atau diyakini sebagai pedoman hidup dan sebagai kebenaran mutlak maka akan 
memiliki nilai dinamis, universal, fleksibel dan berorientasi kedepan baik bagi para penganutnya. Dengan begitu dinamika kehidupan beragama dapat dilihat dari para penganutnya (Ghazali \& Busro, 2017).

Inga dasa uma (bantu membangun rumah)

Inga dasa uma adalah bentuk gotong royong. Perbedaan agama yang diyakinin masyarakat donggo dusun nggerukopa bukan lagi menjadi penghambat dan menutup diri dalam melakukan dan melaksanakan kehidupan sehari-hari tanpa berintraksi dengan kelompok lain hanya karena perbedaan agama yang dianut. Agama yang diakui, diikuti, atau diyakini sebagai pedoman hidup dan sebagai kebenaran mutlak maka akan memiliki nilai dinamis, universal, fleksibel dan berorientasi kedepan baik bagi para penganutnya. Dengan begitu dinamika kehidupan beragama dapat dilihat dari para penganutnya (Ghazali \& Busro, 2017).

Batu rawi rasa (ikutserta dalam acara)

Batu rawi rasa, kegiatan ini menjadi kewajiban dilakukan oleh tiap orang terhadap orang lain sebagai bentuk kaco'i angi tadi walaupun pembuat acara bukanlah dari agama yang sama. Perbedaan agama yang diyakinin masyarakat donggo dusun nggerukopa bukan lagi menjadi penghambat dan menutup diri dalam melakukan dan melaksanakan kehidupan sehari-hari tanpa berintraksi dengan kelompok lain hanya karena perbedaan agama yang dianut. Agama yang diakui, diikuti, atau diyakini sebagai pedoman hidup dan sebagai kebenaran mutlak maka akan memiliki nilai dinamis, universal, fleksibel dan berorientasi kedepan baik bagi para penganutnya. Dengan begitu dinamika kehidupan beragama dapat dilihat dari para penganutnya (Ghazali \& Busro, 2017).

Tio kasama weki rasa ra dana (menjaga bersama desa dan kampung)

Tio kasama weki dana ra rasa. Hal ini sudah melekat pada diri masarakat donggo khususnya Nggerukopa untuk berpartisipasi dalam menjaga keamanan dan ketentraman wilayah, kampung tempat mereka tinggal. Perbedaan agama yang diyakinin masyarakat donggo dusun nggerukopa bukan lagi menjadi penghambat dan menutup diri dalam melakukan dan melaksanakan kehidupan sehari-hari tanpa berintraksi dengan kelompok lain hanya karena perbedaan agama yang dianut. Agama yang diakui, diikuti, atau diyakini sebagai pedoman hidup dan sebagai kebenaran mutlak maka akan memiliki nilai dinamis, universal, fleksibel dan berorientasi kedepan baik bagi para penganutnya. Dengan begitu dinamika kehidupan beragama dapat dilihat dari para penganutnya (Ghazali \& Busro, 2017)

\section{KESIMPULAN}

Pluralisme masyarakat adat donggo dalam merawat kerukunan beragama di Nggerukopa merupakan bagian dari isi sila ke-3 pada pancasila sebagai dasar negara. Persatuan Indonesia memiliki makna yang luas. Hidup rukun, bertoleransi, saling menghargai, menciptakan perdamaian dan keamanan di negara tanpa saling menjatuhkan, merusak, menghianati serta tidak terjadinya konflik karena perbedaan suku, ras dan agama. Itu semua merupakan bentuk persatuan bernegara. Bentuk pluralisme dan kerukunan yang terjadi didusun Nggerukopa ialah jiwa warganegara yang memahami idiologi negara. Kemudian cara masyarakat merawat kerukunan beragama tersebut perlu di apresiasi baik oleh pemerintah maupun oleh masyarakat lain.

\section{SARAN}

Bentuk kerukunan dalam merawat kerukunan beragama yang disajikan oleh peneliti dalam penelitian ini tidak hanya diterapkan bagi masyarakat donggo di dusun Nggerukopa desa Palama. Namun, setiap orang dan masyarakat lain dapat menerapkan ditempat masing-masing, baik beda agama bahkan sesama agama yang daunt. Karena manusia yang baik adalah manusia yang memiliki rasa toleransi dan hidup rukun sesama manusia.

\section{UCAPAN TERIMA KASIH}

Segala bentuk aktivitasi dalam penelitian ini tidak dapat berjalan dengan lancar tanpa campur tangan positif dari pelbagai pihak. Puji syukur tentu diucapkan atas kehadirat Allah SWT, yang telah menganugerahkan ilmu pengetahuan dan nikmat sehat wal'afiat, dalam proses penyelesaian penelitian ini. Peneliti mengucapkan terima kasih kepada pihak pemerintah yang telah mendanai penelitian ini. Kemudian kepada ketua tercinta STKIP Harapan Bima yang telah memberikan fasilitas dalam menunjang penelitian ini. Selanjutnya kepada pihak agama islam, Katolik, dan Protestan yang telah memberikan izin untuk meneliti kerukunan agama ini. Terima kasih pula kami sampaikan kepada rekan-rekan terhebat yang membantu proses penyelesaian penelitian ini. 


\section{DAFTAR PUSTAKA}

Casram. (2016). Membangun Sikap Toleransi

Beragama dalam Masyarakat Plural, Jurnal Ilmiah Agama dan Sosial Budaya 1, (2) 187-198.

Ghazali, A. M., \& Busro. (2017). Pendidikan Islam dalam Dinamika Kehidupan Beragama di Indonesia, Intizar, 23(1) 100103.

I Made Purna. (2016). Kearifan Lokal Masyarakat Desa Mbawa Dalam Mewujudkan Toleransi Beragama. Balai Pelestarian Nilai Budaya Bali, NTB, NTT, Pendidikan dan Kebudayaan, 1 (2) 60-70.

Lestari, Julita. (2020). Pluralisme Agama di Indonesia Tantangan dan Peluang Bagi Keutuhan Bangsa, Religious Studies, 1 (1) 80-90.

Masyithoh, Novita Dewi. (2016). Dialektika Pluralisme Hukum: Upaya Penyelesaian Masalah Ancaman Keberagaman dan Keberagamaan di Indonesia, Religious Studies, 1 (1) 40-50.

Proctor, James. D. (2005). Science, Religion and the Human Experience.p46. New York: Oxford University Press.

Purna, I Made. (2016). Kearifan Lokal Masyarakat Desa Mbawa Dalam Mewujudkan Toleransi Beragama. Balai Pelestarian Nilai Budaya Bali, NTB, NTT, Jurnal Pendidikan dan Kebudayaan, 1 (2) 12-13.

Purna, I Made. (2016). Kearifan Lokal Masyarakat Desa Mbawa dalam Mewujudkan Toleransi Beragama. Balai Pelestarian Nilai Budaya Bali, NTB, NTT. Jurnal Pendidikan dan Kebudayaan, 1 (2) 203-204.

Sugiyono. (2017). Metode Penelitian Kuantitatif, Kualitatif, dan R\&D. p.50. Bandung: Alfabeta.

Sumbulah, Umi. (2015). Pluralisme dan Kerukunan Umat Beragama Perspektif Elite Agama di Kota Malang. Tesis. Universitas Negeri Malang.

Sumitro. (2020). Pelestarian Nilai Budaya Kaco'i Angi Pada Masyarakat Donggo. Equilibrium, 8 (1) 20-22. 